\title{
PERENCANAAN DAN PENGENDALIAN PRODUKSI DENGAN MENGGUNAKAN METODE MANUFACTURING RESOURCES PLANNING DI PT. SEMEN GRESIK TBK
}

I k s a n

Jurusan Teknik Industri

Institut Teknologi Adhi Tama Surabaya

Email :xsn_faruq@yahoo.com

\begin{abstract}
$\mathrm{P}$ T. Cement Gresik represent big company which is moving in the field of construction material making (cement), where till now still execute the cement production for accomplishment of big enough target, although we know that in this time the economics of state still be drawn also raw material with maximal amount. Therefore to be able to productive in an optimal fashion need by the existence of a planning and controlling the raw material use. The application of manufacturing resources planning (MRP II) method is represent one of the method used for production planning and controlling which is exploited by as optimal as possible utilize to reach the target from production executor. With the MRP II analysis can calculate about the product amount produced, production time, also the raw material required so that knowable later whether the production plan need repair existence in the process or not.

The result obtained from analysis that is with method MRP II i.e. the data patterns taken is Single Exponential Smoothing with the smallest MAPE that is $19 \%$, while from the calculation of MRP II found on the result of MRP calculation about requirement of overall raw material experience increase equal to 3.920.653 ton/year and also at CRP calculation experience lack of production time capacities equal to 1528967,7 hour/period which is as the effect from the company policy in determination of the productions amount too high and also maximal machine capacities, so that needed by improvement in the production plan. Effort of repair mentioned by as an alternative that is by refunctioning machine which have time to be desisted and addition of the machine but cannot totally because capacities of maximal raw material existing also determination of production target the needed of seeing machine capacities.
\end{abstract}

Keyword : PPIC, Manufacturing Resources Planning (MRP II)

\section{PENDAHULUAN}

Salah satu dari beberapa hal penting dari sebuah proses produksi adalah bahan baku baik secara langsung maupun tidak langsung, dimana jumlah bahan baku perlu diperhatikan karena bila terjadi kelebihan dalam arti jumlah yang dibutuhkan lebih sedikit dari yang tersedia atau sebaliknya, maka akan dapat merugikan perusahaan yaitu memperbesar biaya operasional. Bahan baku yang paling utama pada PT. Semen Gresik Tbk adalah tanah kapur juga tanah liat serta bahan utama lainnya atau bahan penunjang dalam jumlah cukup besar yang merupakan salah satu perusahaan yang berperan besar dalam menunjang sektor pembangunan. Berdasarkan evaluasi tergambarkan bahwa PT. Semen Gresik Tbk dalam memproduksi produk semen secara terus menerus, oleh karena itu dibutuhkan suatu perencanaan dalam pengambilan dan pengendalian bahan baku, mengingat bahan baku yang tidak bisa diperbarui dan juga agar dapat membuat rencana pemakaian bahan baku yang optimal. Dengan adanya produksi yang terus menerus serta pemakai bahan baku itu mengakibatkan akan adanya penumpukan produk digudang dan bahan baku yang terlalu banyak akan mengakibatkan biaya perawatan akan meningkat. Pimpinan produksi haruslah melaksanakan perencanaa dan pengendalian dalam pemakaian bahan baku yang berlebihan sedangkan produksi tetap berjalan sehingga nantinya permintaan pasar akan terpenuhi tanpa pemakaian bahan baku secara terus menerus.

Manufacturing Resource Planning ( MRP II ) menawarkan sebuah solusi perencanaan produksi maupun perencanaan kapasitas yang dapat diterapkan. Dimana sistem MRP II mengkoordinasikan keseluruhan aspek baik aspek produksi maupun aspek pemasaran. Sehingga dengan MRP II kita dapat membuat rencana produksi (production plant), jadwal induk produksi (master production schedule) yang mencakup bagian inventori dan pembelian, material, bagian rekayasa, produksi dan lain - lain. Selain itu kita bisa membuat Rought Cut Capacity Planning $(R C C P)$ yang bisa mengkonversikan rencana 
produksi atau MPS kedalam kebutuhan kapasitas yang berhubungan dengan sumber - sumber daya kritis. Terakhir kita dapat menyusun CRP (Capacity Requirement Planning) untuk analisa lanjutan berkenaan kebutuhan bahan kapasitas. Dengan demikian perusahaan dalam proses produksi dapat lebih tersistematis dan terencana.

Dari latar belakang diatas maka perumusan masalah yang akan diangkat dalam penelitian ini adalah : Bagaimanakah membuat rencana produksi agar sesuai dengan kapasitas perusahaan? Bagaimana menentukan sumber daya ( bahan baku ) agar dapat mengoptimalkan biaya produksi ?

Tujuan dan manfaat

1. Membuat rencana produksi agar sesuai dengan kapasitas perusahaan.

2. Pengoptimalan sumber daya ( bahan baku )agar dapat mengoptimalkan biaya produksi.

Manfaat yang dapat diambil dari penelitian ini adalah Dengan adanya pengendalian bahan baku yang optimal, maka biaya yang berkaitan dengan bahan baku dapat diminimumkan, sehingga diperoleh adanya penghematan biaya dan dapat meningkatkan keuntungan perusahaan serta meningkatkan daya saingnya. Dapat membantu kelancaran proses produksi dalam menghasilkan produk jadi yang sesuai dengan yang direncanakan, sehingga dapat memenuhi kebutuhan konsumen tepat pada waktunya dan secara tidak langsung dapat menaikkan kepercayaan konsumen terhadap perusahaan.

Perencanaan dan Pengendalian Produksi didefinisikan sebagai proses untuk merencanakan dan pengendalian aliran material yang masuk mengalir dan keluar dari sistem produksi atau opersi sehingga permintaan pasar dapat dipenuhi dengan tepet dan biaya yang minimum. Perencanaan produksi merupakan tindakan antisipasi dimasa mendatang sesuai periode waktu yang direncanakansebagai pendayagunaan sumber daya khususnya material dengan tujuan menentukan arah awal dari tindakan - tindakan yang harus dilakukan dimasa mendatang, apa yang harus dilakukan, berapa banyak melakukan dan kapan harus melakukan. Sedangkan pengendalian produksi merupakan tindakan yang menjamin bahwa semua kegiatan dilaksanakan dalam perencanaan telah dilakukan sesuai dengan target yang telah ditetapkan.

Dengan demikian peranan perencanaan dan pengendalian produksi adalah semata - mata dimaksudkan untuk mengkoordinasikan kegiatan dari bagian - bagian yang langsung maupun tidak langsung dalam berproduksi, merencanakan, menjadwalkan dan pengendalian kegiatan produksi dari mulai dari bahan baku, proses sampai out put yang dihasilkan sehingga perusahaan itu betul betul dapat menghasilkan produk dengan efektif dan efisien.

Material Requirement Planning (MRP) merupakan metode perencanaan bahan baku dengan memanfaatkan informasi tentang ketergantungan pada permintaan manajemen persediaan dan pengendalian ukuran lot produksi dari berbagai komponen yang diperlukan untuk membuat produk akhir. Konsep MRP menyiapkan jadwal pesanan agar jumlah material atau bahan baku yang dipesan akan datang tepat pada waktunya, sehingga proses produksi akan dapat dikerjakan pada waktunya.

Sistem MRP disusun dengan maksud untuk menjawab kapan, berapa banyak dan apa suatu material dibutuhkan secara tepat tanpa mengeluarkan biaya terlalu besar. MRP memang komplek pengelolaannya tetapi banyak memberikan keuntungan, seperti mengurangi persediaan dan biay penyimpanan, memberikan informasi untuk mendukung tindakan yang tepat, baik pembatalan pesanan atau penjadwalan ulang.

Penjelasan yang berkaitan dengan format tampilan dari MRP I adalah sebagai berikut :

1. Lead Time merupakan jangka waktu yang dibutuhkan sejak MRP menyarankan suatu pesanan sampai item yang dipesan itu siap untuk digunakan.

2. On Hand merupakan inventory on - hand yang menunjukkan kuantitas dari item yang secara fisik ada dalam stockroom.

3. Lot Size merupakan kuantitas pesanan (order quantity) dari item yang memberitahukan MRP berapa banyak kuantitas yang harus dipesan serta teknik lot-sizing apa yang dipakai. Teknik yang dipakai dalam menentukan ukuran lot size adalah : a. Fized Order Quantity (jumlah pemesanan tetap) adalah Teknik ini merupakan konsep jumlah pemesanan tetap, penentuan besarnya lot size dapat sekehendak kita, melalui intuisi sesuai dengan pengalaman si pemakai. Besarnya jumlah pesanan mencerminkan pertimbangan eksternal. b. Economic Order Quantity (jumlah pemesanan ekonomis) Nilai EOQ digunakan untuk menentukan ukuran 
lot size (nilainya tetap) perhitungannya sudah mencakup ongkos pesan dan ongkos simpan. c. Lot For Lot kebijakan ini ukuran lot size dilakukan atas pesanan diskrit. Jumlah yang dipesan sama jumlahnya dengan jumlah yang dibutuhkan dalam kebutuhan bersih. Setelah itu dihitung biaya total yang diperoleh dari penjumlahan biaya pemesanan dan biaya penyimpanan. d. Fixed Order Inventory (FOI) Teknik ini dipakai untuk menggambarkan konsep pemesanan dengan interval berubah dan jumlah yang dipesan bervariasi. Kekurangan bahan baku bisa terjadi setiap saat. Setiap kali pemesanan gudang akan terisi penuh dengan bahan baku.

4. Safety Stock merupakan stok pengaman yang ditetapkanolehperencanaMRPuntukmengatasi fluktuasi dalam permintaan (demand) dan/atau penawaran (supply).

5. Planning Horizon merupakan banyaknya waktu ke depan (masa mendatang) yang tercakup dalam perencanaan.

6. Gross Requirements merupakan total dari semua kebutuhan, termasuk kebutuhan yang diantisipasi (anticipated requirements), untuk setiap periode waktu.

7. Projected On - Hand merupakan projected available balance (PAB), dan tidak termasuk planned orders.

8. Projected Available merupakan kuantitas yang diharapkan ada dalam inventori pada akhir periode, dan tersedia untuk penggunaan dalam periode selanjutnya.

9. Net Requirements merupakan kekurangan material yang diproyeksikan untuk periode ini, sehingga perlu diambil tindakan ke dalam perhitungan planned orders receipts agar menutupi kekurangan material pada periode itu.

10. Planned Order Receipts merupakan kuantitas pesanan pengisian kembali (pesanan manufakturing dan/atau pesanan pembelian) yang telah direncanakan oleh MRP untuk diterima pada periode tertentu guna memenuhi kebutuhan (net requirements).

11. Planned Order Releases merupakan kuantitas planned oreders yang ditempatkan atau dikeluarkan dalam periode tertentu, agar item yang dipesan itu akan tersedia pada saat dibutuhkan.

Perencanaan Produksi pada dasarnya merupakan suatu proses penetapan tingkat output manufacturing secara keseluruhan guna memenuhi tingkat penjualan yang direncanakan dan inventori yang diinginkan. Rencana produksi harus konsisten dengan rencana bisnis, yang dalam sistem MRP II merupakan input bagi proses perencanaan produksi. Terdapat empat tingkat dalam hierarki perencanaan prioritas dan kapasitas yang terintegrasi, antara lain : Perencanaan Produksi dan Perencanaan Kebutuhan Sumber daya, Penjadwalan Produksi Induk ( MPS ) dan Rough Cut Capacity Planning ( $R C C P$ ) . Perencanaan Kebutuhan Material (MRP) dan Perencanaan Kebutuhan Kapasitas (CRP). Pengendalian Aktivitas Produksi (PAC) dan Pengendalian Input/Output serta Operations Sequencing. Pada dasarnya dalam sistem MRP II terdapat tiga alternatif strategi perencanaan produksi, yaitu : level method, chase strategy, dan compromise strategy.

a. Level Method didefinisikan sebagai metode perencanaan produksi yang mempunyai distribusi merata dalam produksi. Dalam perencanaan produksi, level method akan mempertahankan tingkat kestabilan produksi sementara menggunakan inventori yang bervariasi untuk mengakumulasi output apabila terjadi kelebihan permintaan total.

b. Chase Strategy didefinisikan sebagai metode perencanaan produksi yang mempertahankan tingkat kestabilan inventori, sementara produksi bervariasi mengikuti permintaan total.

c. Compromise Strategy merupakan kompromi anatara kedua metode perencanaan produksi diatas

Sistem Manufacturing Resources Planning ( MRP II ) Pada dasarnya merupakan suatu sistem informasi manufaktur formal dan eksplisit yang mengintegrasikan fungsi - fungsi utama dalam industri manufaktur, seperti : keuangan, pemasaran, dan produksi. Sistem MRP II mencakup dan mengintegrasikan semua aspek bisnis dari perusahaan industri manufaktur, sejak perencanaan strategi bisnis pada tingkat manajemen puncak (Top Management) sampai perencanaan dan pengendalian terperinci pada tingkat manajemen dan supervisor". (Analysis and Control of Production Sistems, Elsayed \& Thomas O. Boucher, 1994 : 31). Manufacturing Resources Planning ( MRP II ) membantu kita untuk dapat 
mengubah bentuk wajah perindustrian kita. Hal itu memungkinkan kita membuat peningkatan dalam perusahaan manufaktur seperti yang terjadi di seluruh Amerika Utara, Jepang, Eropa Barat, dan Amerika Latin. Suatu definisi Manufacturing Resources Planning ( MRP II ) yang tepat dan terperinci yang memungkinkan untuk dipahami oleh kita adalah : "Suatu perusahaan sistem manajemen lebar/luas berdasar pada penjadwalan, yang mana memungkinkan kita dengan tingkat pelayanan pelanggan yang tinggi dan produktivitas yang secara serempak dapat menurunkan biaya dan inventori “. (MRP II: Making It Happen, Thomas
F. Wallace, 1990 : 3). MRP II merupakan suatu sistem informasi terintegrasi yang menyediakan data di antara berbagai aktivitas produksi dan area fungsional lainnya dari bisnis secara keseluruhan. Sistem MRP II mengkoordinasikan pemasaran, manufacturing, pembelian, dan rekayasa melalui pengadopsian rencana produksi serta melalui penggunaan satu data base terintegrasi guna merencanakan dan memperbaharui aktivitas dalam sistem industri modern secara keseluruhan, dari pada MRP I sebagai single level dan juga merupakan adalah satu dari elemen - elemen MRP II.

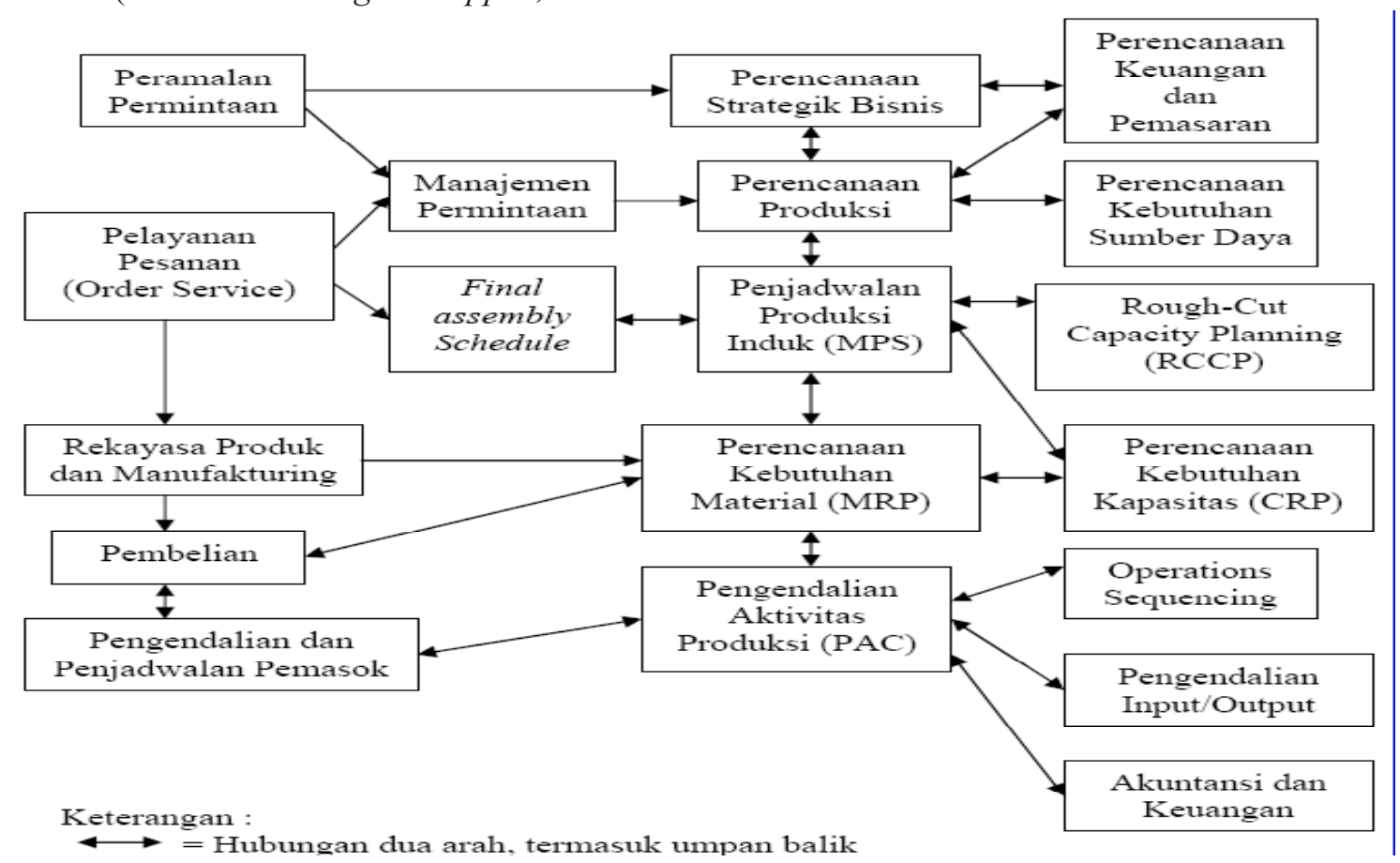

$$
\begin{aligned}
& \overleftrightarrow{\longrightarrow}=\text { Hubungan dua arah, termasuk umpan balik } \\
& M P S=\text { Master Production Scheduling } C R P=\text { Capacity Requirement Planning } \\
& M R P=\text { Material Requirement planning } P A C=\text { Production Activity Control }
\end{aligned}
$$

Gambar Sistem Manufacturing Resources Planning ( MRP II )

(Sumber :Vincent Gaspersz, 2002 : 31)

\section{Master Production Schedule}

Pada dasarnya jadwal induk produksi (Master Production Schedule $=$ MPS) merupakan suatu pernyataan tentang produk akhir (termasuk parts pengganti dan suku cadang) dari suatu perusahaan industri manufaktur yang merencanakan memproduksi output berkaitan dengan kuantitas dan periode waktu. MPS mendisagregasikan dan mengimplementasikan rencana produksi. Apabila rencana produksi yang merupakan hasil dari proses perencanaan produksi dinyatakan dalam bentuk agregat, MPS yang merupakan hasil dari proses penjadwalan induk produksi dinyatakan dalam konfigurasi spesifik dengan nomor-nomor item yang ada dalam item master dan BOM (Bill Of Material) files.

Aktivitas penjadwalan produksi induk (MPS) pada dasarnya berkaitan dengan bagaimana menyusun dan memperbaharui jadwal produksi induk (MPS), memproses transaksi dari MPS, memelihara catatan-catatan MPS, mengevaluasi efektifitas dari MPS, mengevaluasi dalam periode waktu yang teratur untuk keperluan umpan-balik dan tinjauan ulang.

Sebagai suatu aktivitas proses, penjadwalan produksi induk (MPS) membutuhkan lima input utama, dapat dijelaskan beberapa hal berikut : 
a. Data Permintaan Total merupakan salah satu sumber data bagi proses penjadwalan produksi induk. Data permintaan total berkaitan dengan ramalan penjualan (sales forecasts) dan pesananpesanan (orders).

b. Status Inventori berkaitan dengan informasi tentang on-hand inventory, stok yang dialokasikan untuk penggunaan tertentu (allocated stock), pesanan-pesanan produksi dan pembelian yang dikeluarkan (released production and purchase orders), dan firm planned orders. MPS harus mengetahui secara akurat berupa banyak inventori yang tersedia dan menentukan berapa banyak yang harus dipesan.

c. Rencana Produksi memberikan sekumpulan batasan kepada MPS. MPS harus menjumlahkannya untuk menentukan tingkat produksi, inventori, dan sumber-sumber daya lain dalam rencana produksi itu.

d. Data Perencanaan berkaitan dengan aturanaturan tentang lot-sizing yang harus digunakan, shrinkage factor, stok pengaman (safety stock), dan waktu tunggu (lead time) dari masingmasing item yang biasanya tersedia dalam file induk dari item (item master file).

e. Informasi dari RCCP berupa kebutuhan kapasitas untuk mengimplementasikan MPS menjadi salah satu input bagi MPS.

\section{Rought Cut Capacity Planning (RCCP)}

Rought Cut Capacity Planning (RCCP) mengukur kapasitas yang dibutuhkan untuk melaksanakan MPS. Rencana ini berdasarkan pada informasi yang lebih detail daripada rencana sumber daya karena RCCP mencakup jadwal dari spesifik komponen akhir, RCCP menghitung beban untuk semua item yang dijadwalkan dan dalam periode waktu aktual. Apabila proses RCCP mengindikasikan bahwa MPS adalah layak, MPS akan diteruskan ke proses MRP guna menentukan bahan baku atau material, komponen dan sub assemblies, yang dibutuhkan dalam perusahaan yang berorientasi pada kapasitas.

\section{Capacity Requirement Planning (CRP)}

CapacityRequirementPlanning(CRP)dilakukan setelah RCCP menunjukkan bahwa jadwal produksi mungkin dilaksanakan. CRP menggunakan output MRP dan menghasilkan profil kapasitas terperinci untuk semua sumber daya untuk tiap mingguan (atau lebih sedikit) sesuai dengan perencanaan. (Analysis And Control Of Production Systems, Elsayed \& Thomas O. Boucher, 1994 : 215)

MRP mengasumsikan bahwa apa yang dijadwalkan dapat diterapkan, tanpamemperhatikan keterbatasan kapasitas. Kadang - kadang asumsi ini valid, tetapi kadang - kadang tidak dapat dipenuhi. Perencanaan kebutuhan kapasitas (RCP) menguji asumsi ini dan mengidentifikasikan area yang melebihi kapasitas (overload) dan yang berada di bawah kapasitas (underload), sehingga perencana dapat mengambil tindakan yang tepat. CRP membandingkan beban (load) yang ditetapkan pada setiap pusat kerja (work center) melalui open and planned orders yang diciptakan oleh MRP, dengan kapasitas yang tersedia pada setiap pusat kerja dalam periode waktu dari horizon perencanaan. Tidak seperti sistem MRP yang menciptakan new planned orders untuk menghindari kekurangan material atau item di masa mendatang, sistem CRP tidak menciptakan, menjadwalkan ulang, atau menghapus pesanan apa pun. Sebagai suatu sistem perencanaan kapasitas dalam sistem MRP II yang lebih besar, CRP memiliki input, proses, output, dan umpan balik. Sistem CRP ditunjukkan dalam gambar berikut :

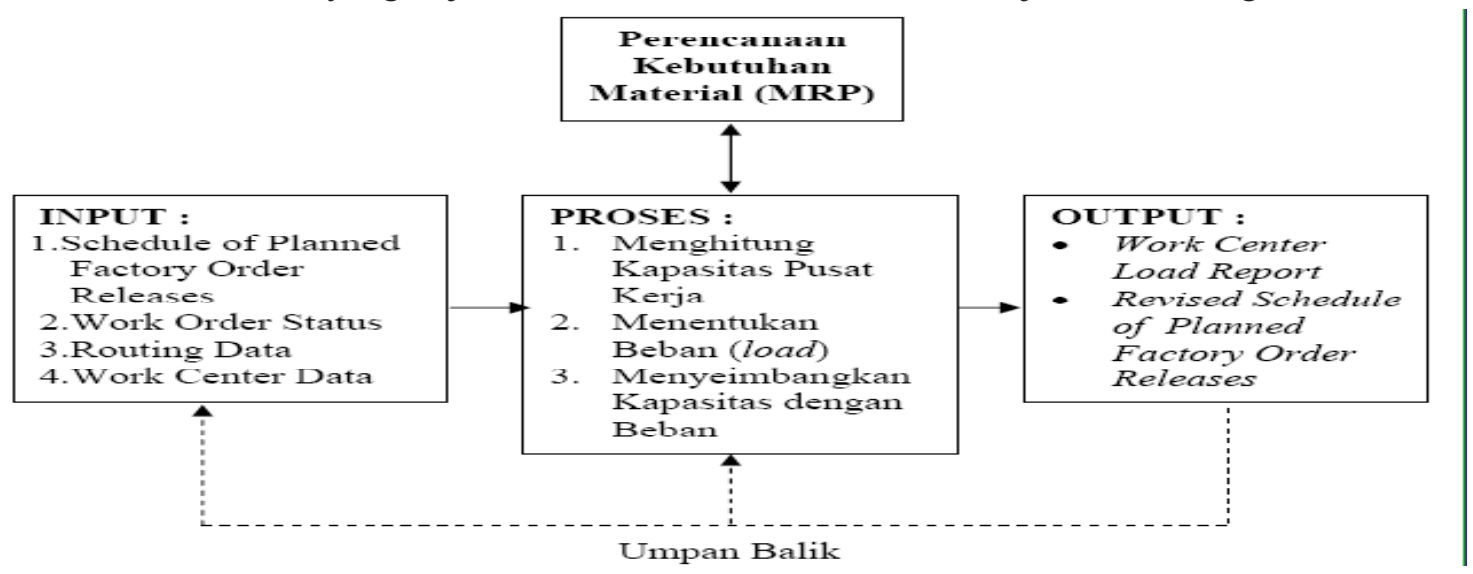

Gambar 2. Sistem Perencanaan Kebutuhan Kapasitas (CRP) 


\section{Metode Pengukuran Kapasitas}

Pada dasarnya terdapat tiga metode pengukuran kapasitas, yaitu :

a. Theoretical Capacity (synonym : Maximum Capacity, Design Capacity) merupakan kapasitas maksimum yang mungkin dari sistem manufakturing yang didasarkan pada asumsi mengenai adanya kondisi ideal seperti : tiga shift per hari, tujuh hari per minggu, tidak ada downtime mesin, dll. Dengan demikian theoretical capacity diukur berdasarkan pada jam yang tersedia untuk melakukan pekerjaan, tanpa suatu kesempatan untuk berhenti atau istirahat, downtime mesin, atau alasan lainnya.

b. Demonstrated Capacity (synonym: Actual Capacity, Effective Capacity) merupakan tingkat output yang dapat diharapkan berdasarkan pada pengalaman, yang mengukur produksi secara aktual dari pusat kerja di waktu lalu, yang biasanya diukur menggunakan angka rata-rata berdasarkan beban kerja normal.

c. Rated Capacity (synonym: Calculated Capacity, Nominal capacity) diukur berdasarkan penyesuaian kapasitas teoretis dengan faktor produktivitas yang telah ditentukan oleh demonstrated capacity. Dihitung melalui penggandaan waktu kerja yang tersedia dengan faktor utilisasi dan efisiensi.

Waktu kerja yang tersedia adalah banyaknya jam kerja aktual yang dijadwalkan atau tersedia, pada pusat kerja selama periode tertentu. Waktu kerja yang tersedia per periode waktu dihitung sebagai : banyaknya orang atau mesin $x$ jam per shift $x$ shifts per hari $x$ hari kerja per periode.

Utilisasi adalah pecahan yang menggambarkan persentase clock time yang tersedia dalam pusat kerja yang secara aktual digunakan untuk produksi berdasarkan pengalaman lalu. Utilisasi dapat ditentukan untuk mesin atau tenaga kerja, atau keduanya, tergantung pada mana yang lebih cocok untuk situasi dan kondisi aktual di perusahaan. Perlu dicatat bahwa angka utilisasi tidak dapat melebihi 1,0 (100\%). Formula untuk menghitung utilisasi adalah :

Utilisasi $=\frac{\text { Jam aktual yang digunakan untuk produksi }}{\text { Jam yang tersedia menurut jadwal }}$

Efisiensi adalah faktor yang mengukur performansi aktual dari pusat kerja relatif terhadap standar yang ditetapkan. Faktor efisiensi dapat lebih besar dari 1,0. Formula untuk mengitung efisiensi adalah :

$$
\text { Efisiensi }=\frac{\text { Jam standar yang diperoleh atau diproduksi }}{\text { Jam aktual yang digunakan untuk produksi }}
$$

Dengan demikian rated (or calculated) capacity dihitung sebagai berikut:

Calculated capacity per periode

= banyaknya orang atau mesin $x$ jam per shift

$x$ shifts per hari $x$ hari kerja per periode $x$ utilisasis $x$ efisieni

$=$ waktu yang tersedia per periode waktu $x$ utilisasi $x$ efisiensi

\section{METODE}

Rencana penelitian yang akan digunakan adalah

Tabel 1. Rencana Penelitian

\begin{tabular}{|l|l|}
\hline Rancangan Penelitian & \multicolumn{1}{c|}{ Proses Perolehan } \\
\hline Sampel & $\begin{array}{l}\text { Diambil dari data - data yang mempunyai relevansi dengan metode MRP II berupa } \\
\text { : data struktur produk, BOM, kapasitas produksi, data permintaan produk, data } \\
\text { inventori, JIP, dan lain - lain. }\end{array}$ \\
\hline Sumber Data & $\begin{array}{l}\text { Data Primer (secara langsung berupa data proses dan waktu produksi). } \\
\text { Data Sekunder (secara tidak langsung yaitu berupa dokumen perusahaan, berupa } \\
\text { data permintaan, data produk, mesin, peralatan dan lain - lain ). }\end{array}$ \\
\hline Instrumen & $\begin{array}{l}\text { Literatur, interview, observasi, serta dokumentasi. } \\
\text { Analisis Data }\end{array}$ \\
\hline
\end{tabular}

Untuk mendapatkan data dan informasi yang dapat dipergunakan untuk penelitian penulis langsung ke lapangan. Pengambilan data tersebut dilakukan dengan metode sebagai berikut : Pengumpulan data dengan cara melakukan tanya jawab langsung mengenai permasalahan yang akan diteliti. Pertanyaan - pertanyaan yang diajukan antara lain : - Bagaimana proses produksi ? Sistem produksi apa yang dipakai perusahaan ? . Berapa jumlah tenaga kerja ? . Berapa jam satu shift dan satu hari ada berapa shift ?. Berapa lama lead time produk ? Dan lain -lain. Observasi, dimana penulis mengadakan pengamatan langsung terhadap keadaan yang sebenarnya terjadi serta hal 
- hal yang berkaitan dengan permasalahan yang diteliti. Data - data yang didapat antara lain data waktu standart, alur dari proses produksi, jenis mesin, kondisi mesin, lay out pabrik dan lain lain. Pengumpulan data yang didapat dari laporan atau catatan-catatan dari pabrik. Data - data yang diperoleh antara lain permintaan produk masa lalu, struktur produk, Bill of Material, data inventori dan lain-lain.

Adapun langkah - langkah Penelitian Dan Pengolahan Data nya adalah sebagai berikut :

Studi Kepustakaan ; penyusun membaca literatur dan buku-buku yang berkaitan produktivitas. Hal ini dilakukan dengan tujuan agar penulis memperoleh gambaran tentang perencanaan produksi, seperti pengertian MRP II dan model-model pengukuran MRP II. Penelitian ke perusahaan yang dilakukan peneliti terhadap perusahaan yang dijadikan objek penelitian. Penulis melakukan penelitian di PT. SEMEN GRESIK Tbk. Mengidentifikasi pokok permasalahan yang akan diteliti, kemudian dilanjutkan dengan perumusan masalah-masalah yang menjadi objek penelitian. Penentuan Tujuan ; Setelah merumuskan permasalahan, menentukan tujuan penelitian merupakan hal yang terpenting yang dapat memberi arahan yang jelas tentang pelaksanaan penelitian selanjutnya.

Metode pengumpulan data yang dilakukan untuk mendapatkan informasi dan data dari objek penelitian. Cara atau teknik yang digunakan dalam melakukan pengumpulan data ini adalah: a. Interview merupakan metode pengumpulan data yang dilakukan dengan cara tanya jawab langsung dengan pihak yang berhubungan dengan perusahaan. Biasanya berupa data pembobotan terhadap kriteria yang akan diukur. b. Dokumentasi adalah teknik pengumpulan data dan informasi dengan cara melakukan pencatatan terhadap data asli perusahaan.

Pengolahan data dengan MRP II ; Setelah informasi-informasi yang mempengaruhi masalahmasalah yang terkait dengan sistem produksi yang diperoleh, maka dapat dilakukan perhitungan agar dapat lebih mudah untuk dipahami yang meliputi identifikasi penyebabnya dan mencari alternatif solusi yang baik. Evaluasi Sistem Produksi ; Melakukan analisa dan evaluasi terhadap sumber daya yang diperoleh dari pengolahan data dengan MRP II. Dengan melakukan evaluasi kita dapat mengetahui faktor-faktor apa saja yang mempengaruhi sistem produksi perusahaan, sehingga kita dapat mengambil langkah perbaikan. Usulan perbaikan Sistem Produksi ; Data dari analisis selanjutnya merupakan masukan untuk dilakukannya perencanaan pengoptimalan sumber daya. Setelah dilakukan analisa, akan didapatkan perencanaan produksi periode mendatang. Hal ini digunakan sebagai acuan dalam merencanakan perbaikan rencana produksi periode selanjutnya. Kesimpulan ; Setelah diperoleh pemecahan masalah maka langkah selanjutnya adalah menarik kesimpulan dari hasil analisa dan memberikan saran-saran yang bermanfaat bagi perusahaan.

\section{HASIL DAN PEMBAHASAN}

Dari hasil peramalan permintaan yang telah didapat kemudian dijadikan Master Production Schedule ( MPS ) untuk pembuatan perencanaan kebutuhan material dan penentuan kapasitas produksi yang dibutuhkan. Untuk tabel hasil perhitungan MPS produk yang dibahas dengan menggunakan lot size lot for lot dapat dilihat pada tabel 4.7. sehingga nilai MPS sama dengan actual demand. MPS yang menyatakan sebuah akhiran yang berupa outputan yang akan diproduksi dimana inputan dari MPS adalah rencana produksi yang merupakan actual demand, dalam proses ini sangat perlu sebuah peramalan karena pemenuhan produksi atas bahan baku yang mungkin harus dikendalikan serta pemenuhan permintaan secara make to order dan direncanakan agar sumber daya (bahan baku), dimana produksi sesuai dengan pesanan atau permintaan pelanggan yang bervariasi karena perusahaan memiliki jenis produk yang bervariasi dan tetap bisa dijaga keberadaannya mengingat bahan baku yang tersedia maksimal.

Rought Cut Capacity Planning (RCCP) mengukur kapasitas yang dibutuhkan untuk melaksanakan MPS. Apabila proses RCCP mengindikasikan bahwa MPS adalah layak, MPS akan diteruskan ke proses MRP guna menentukan bahan baku atau material yang dibutuhkan dalam perusahaan yang berorientasi pada kapasitas. Langkah pertama dalam melaksanakan RCCP adalah memperoleh informasi tentang rencana produksi dari MPS yang hasilnya. Dari hasil RCCP diketahui bahwa setiap bulan mengalami kelebihan waktu terhadap beban kerja yaitu kebutuhan sumber daya yang seharusnya dijadwalkan sudah terpenuhi sebelum periode yang direncanakan oleh karena itu kelebihan waktu tersebut harus disesuaikan dengan setiap periode untuk memenuhi sumber 
daya tersebut.

Setelah dilakukan perhitungan RCCP maka akan dibahas mengenai MRP, dimana sistem MRP disusun dengan maksud untuk menjawab kapan, berapa banyak dan apa suatu material dibutuhkan secara tepat.MRPmemangkomplek pengelolaannya tetapi banyak memberikan keuntungan, seperti mengurangi persediaan dan biaya penyimpanan, memberikan informasi untuk mendukung tindakan yang tepat, baik pembatalan pesanan atau penjadwalan ulang. Metode yang dipakai untuk komponen bahan baku dalam perusahaan ini merupakan metode EOQ, sebagai perbandingan dari hasil MRP dengan menggunakan lot for lot dan FOQ. Perusahaan pada awal tidak punya onhand inventory sedangkan didalam perhitungan dengan menggunakan metode EOQ terdapat penambahan dipersediaan awal dan akhir disetiap bulan dimana perusahaan tidak bisa memenuhi kapasitas mesin dengan adanya permintaan yang cukup banyak, serta adanya pabrik yang tidak berfungsi (mesin-mesin produksi) juga tenaga kerja yang dikurangi. Dengan demikian perusahaan harus bisa mempertimbangkan kestabilan volume permintaan pelanggan melainkan sebaliknya dapat mempertahankan tingkat kestabilan inventory.

Sedangkan biaya yang akan digunakan dalam mengikuti volume bahan baku yang akan diproduksi, dengan melihat hasil dari perhitungan MRP setiap periode adanya penambahan kapasitas bahan baku yang akan menyebabkan biaya yang digunakan tidak optimal sehingga mengalami pembengkakan biaya produksi. Dari perhitungan perbandingan dengan menggunakan ketiga lot size terdapat biaya terkecil yang diperoleh dengan menggunakan metode LFL. Sementara perusahaan menggunakan metode EOQ yang hasilnya dapat dilihat pada tabel.

\begin{tabular}{|c|c|c|c|c|c|}
\hline $\begin{array}{l}\text { Teknik Lot } \\
\text { Sizing }\end{array}$ & $\begin{array}{l}\text { Frekuwensi } \\
\text { Pemesanan }\end{array}$ & $\begin{array}{l}\text { Biaya } \\
\text { (Rp) }\end{array}$ & $\begin{array}{l}\text { J u m l a } \text { a h } \\
\text { Pers e d i a a } \\
\text { dalam (ton) }\end{array}$ & $\begin{array}{l}\text { Biaya Simpan } \\
(\mathbf{R p})\end{array}$ & Biaya total (Rp) \\
\hline LEI & 144 & 7.140 .866 .164 .000 & 0 & 0 & 7.140 .866 .146 .000 \\
\hline $\mathrm{FOO}$ & 144 & 7.140 .866 .146 .000 & 695701970 & 386.581 .484 .800 & 7.527 .447 .649 .000 \\
\hline $\mathrm{EOQ}$ & 141 & 6.992 .098 .119 .000 & 26913219770 & 386.581 .484 .800 & 7.378 .679 .604 .000 \\
\hline
\end{tabular}

Dari analisa biaya di atas maka penghematan yang dapat dilakukan dengan menggunakan sistem MRP II ini sebesar :

Rp. 7.378.679.604.000 - Rp. 7.140.866.164.000 = Rp. 237.813.440.000

Capacity Requirement Planning ( CRP ) membandingkan waktu yang dibutuhkan untuk pelaksanaan produksi pesan yang dihasilkan oleh sistem MRP. CRP menghitung beban pada setiap produksi dengan waktu yang telah tersedia dalam memproduksi per unit yang dihasilkan. Beban dalam CRP menggambarkan set up time yang dibuthkan dalam memproduksi per unit produk. Dalam menganalisa dengan memperoleh informasi tentang pesan produksi yang diperoleh dari perhitungan MRP, selanjutnya informasi tentang waktu-waktu tersebutdigunakan untukmenghitung waktu aktual dengan memperhitungkan utilitas dan efisiensi. Dari analisa CRP diketahui bahwa terjadi kekurangan waktu disetiap bulan dikarenakan mulai awal sudah kita ketahui bahwa tenaga kerja, mesin serta bahan baku yang terbilang maksimal sehingga perusahaan tidak bisa menambah sumber daya secara menyeluruh dan perusahaan perlu melakukan penyesuaian sumber daya dengan cara mesin-mesin yang sempat berhenti difungsikan kembali serta penambahan tenaga kerja untuk mengoptimalkan waktu produksi apabila terjadi kekurangan sumber data waktu. Selain itu juga pihak perusahaan mengadakan kerja sama antara pabrik semen yang ada di Gresik dengan yang ada di Tuban berupa pengiriman bahan baku setengah jadi agar target yang ditetapkan di pabrik semen yang ada di Gresik bisa tercapai.

\section{KESIMPULAN}

Dari hasil penganalisaan permasalahan yang ada, maka didapat kesimpulan bahwa Perencanaan produksi menetapkan tingkat output manufakturing secara keseluruhan untuk memenuhi tingkat permintaan dan inventori yang ada. Dengan strategi perencanaan, perusahaan menggunakan make to order dimana produksi sesuai dengan permintaan pelanggan atau target perusahaan. Dari evaluasi yang dilakukan mulai dari awal diketahui terjadi peningkatan kebutuhan bahan baku sebesar 3.920.653 ton / tahun yang dikarenakan target produksi terlalu tinggi dan sangat beresiko mengingat persediaan bahan baku yang maksimal, sedangkan perusahaan mengalami kekurangan sumber daya waktu sebesar 1528697,7 jam / periode untuk pemenuhan permintaan konsumen (penentuan target produksi) yang dikarenakan 
sumber daya waktu yang ada maksimal.

Yang dilakukan perusahaan untuk pemenuhan permintaan konsumen (target produksi) sangat beresiko melihat kapasitas sumber daya yang ada, khususnya bahan baku yang maksimal. Untuk pemenuhan kebutuhan sumber daya bahan baku (material) yang tepat adalah dengan melakukan perencanaan MRP, yang menunjukkan persediaan akhir dan awal yang terus mengalami peningkatan. Sedangkan biaya produksi yang akan digunakan mengikuti volume bahan baku yang akan diproduksi yang akan menyebabkan biaya yang digunakan tidak optimal sehingga mengalami pembengkakan biaya produksi. Dari perhitungan dengan menggunakan metode MRP II perusahaan dapat menghemat sebesar Rp. 237.813.440.000 serta adanya kerja sama dengan pabrik semen yang ada di Tuban yang akhirnya bisa menutupi kekurangan bahan baku di pabrik semen yang ada di Gresik sehingga bisa mencapai targetnya.

Sebaiknya perusahaan lebih memperhatikan sumber dayabahanbaku(material)yang tersedia dengan mengukur standart produksi sehingga target produksi yang berdasarkan sumber daya yang ada menjadikan terpenuhinya permintaan pelanggan atau target perusahaan. Agar dapat mengatasi kebutuhan sumber daya waktu, perusahaan sebaiknya memperkirakan kapasitas mesin serta kapasitas sumber daya penunjang yang ada lainnya sehingga biaya produksi

\section{DAFTAR PUSTAKA}

Assauri, Sofjan, 1980, “ Manajemen Produksi “, Edisi ketiga, Lembaga penerbit Fakultas Ekonomi Universitas Indonesia, Jakarta

Assauri, Sofjan, 1980, Teknik dan Metoda Peramalan (Penerapannya Dalam Ekonomi dan Dunia Usaha), Edisi Satu, Lembaga Penerbit Fakultas Ekonomi Universitas Indonesia, Jakarta.

Arman Hakim Nasution, 1999, Perencanaan dan Pengendalian Persediaan, Teknik Industri ITS.

Agus Ahyari,1986, Pengendalian Produksi buku I, BPE-Yogyakarta.

Box, George P. and Jenkins, GM., Time Series Analysis Forecasting and Control, Revised Edition, California, Hoden Day In,1976.

Donald J. Bowersox, Manajemen Logistik, PT. Bumi Aksara Jakarta.

Buffa, ES, 1991, “ Manajemen Produksi / Operasi “, Jilid I, Erlangga, Jakarta
Freddy Rangkuti, Manajemen Persediaan Aplikasi di Bidang Bisnis ,PT.Raja Grafindo Persada Jakarta.

Gaspersz, Vincent, 1998, “ Production Planning And Inventory Control

Gaspersz, Vincent, Production Planning and Inventory Control - Berdasarkan Pendekatan Sistem Terintegrasi MRP II dan JIT Menuju Manufakturing 21, PT. Gramedia Pustaka Utama, Jakarta, 2002

Hakim Nasution, Arman, Perencanaan dan Pengendalian Produksi, PT. Candimas Metropole, Jakarta, 1999

Kusuma, Hendra, Manajemen Produksi Perencanaan Pengendalian Produksi, ANDI, Yogya, 2002

Herjanto, Eddy, Manajemen Produksi dan Operasi, PT. Gramedia Widiasarana Indonesia, Jakarta, 1999

Nasution, Arhan Hakim, 1999, " Perencanaan dan Pengendalian Produksi ", Cetakan Pertama, Guna Widya, Jakarta

Setya, Ancan Gunawan, 2004, " Perencanaan Produksi dengan Menggunakan Metode Chase Starategy dan Compromise di PT Sierrad Produce, Tbk ", Skripsi, ITATS, Surabaya

Siswanto,1985, Persediaan Model dan Analisis, Andi Offset Yogyakarta

Sumayang, Lalu, Dasar-dasar Manajemen Produksi dan Operasi, Jakarta, 2003

Triyanto, Bambang, 1991, ” Pedoman Penulisan Karya Ilmiah ", Effhar \& Damara Press, Jakarta.

Zulian Yamit, Manajemen Produksi dan Operasi, Ekonesia Fakultas Ekonomi UII, Yogyakarta

Zulian Yamit, Manajemen Persediaan, Ekonesia Fakultas Ekonomi UII, Yogyakarta 